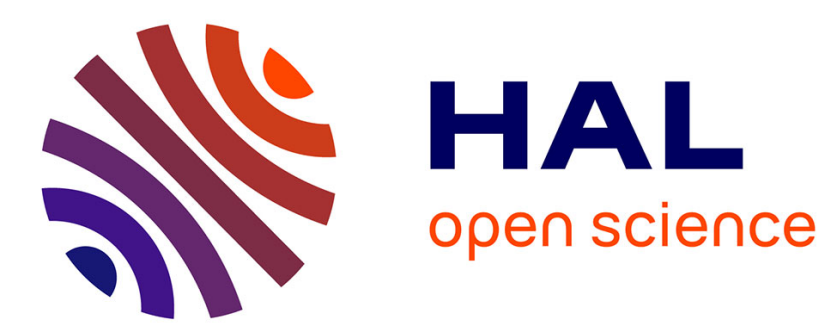

\title{
Adorno's "Schubert": From the Critique of the Garden Gnome to the Defense of Atonalism
}

Esteban Buch

\section{To cite this version:}

Esteban Buch. Adorno's "Schubert": From the Critique of the Garden Gnome to the Defense of Atonalism. 19th-Century Music, 2005, 29 (1), pp.25-30. hal-01044761

\section{HAL Id: hal-01044761 \\ https://hal.inria.fr/hal-01044761}

Submitted on 28 Jul 2014

HAL is a multi-disciplinary open access archive for the deposit and dissemination of scientific research documents, whether they are published or not. The documents may come from teaching and research institutions in France or abroad, or from public or private research centers.
L'archive ouverte pluridisciplinaire HAL, est destinée au dépôt et à la diffusion de documents scientifiques de niveau recherche, publiés ou non, émanant des établissements d'enseignement et de recherche français ou étrangers, des laboratoires publics ou privés. 
Adorno's Schubert:

From the Critique of the Garden Gnome to the Defense of Atonalism

\section{Esteban Buch}

Adorno's "Schubert" was originally published in Die Musik, in the Schubert special issue of October 1928 motivated by the commemoration of the centennial of the composer's death on 19 November $1828 .^{1}$ The author was then twenty-five years old; the first readers of the draft were the philosophers Walter Benjamin and Ernst Bloch. The place of this dense, even enigmatic essay in Adorno's intellectual biography might indeed be crucial, for a consistent line links it with some of the most interesting products of his later years. Yet this piece is but one of literally hundreds of articles, books, lectures and public speeches triggered by the 1928 Schubert Centennial and published in very different media, from scholarly journals to the popular press, all around the Western World. Needless to say, these utterances are not just the product of one day's feelings, but stem from a whole body of concepts, practices, and attitudes that go well beyond the particular significance of one composer to reflect and actualize broader social and political issues.

For example, one critic described a festival gathering in Vienna, where a multitude of people from all over Germany got together to sing massive choral arrangements of Schubert Lieder, as "a purely political demonstration in favor of a re-union of Austria and Germany."2 Leo Kestenberg stressed Schubert's "revolutionary powers" in the field of the Lied, ${ }^{3}$ while in Die Rote Fahne, the organ of the Communist Party, a writer claimed that "the real Schubert belongs to the working people." ${ }^{4}$ In fact, the Centennial itself was a matter of discord. Whereas some saw it as a wonderful expression of the world-wide expansion of the people's sensitivity thanks to the civilising powers of high culture, a Weltfeier amounting to the 
realization of the Goethean ideal of a Weltkunst, ${ }^{5}$ others took it for a worrisome symptom of the trivialization of art music. Consensual in its object, the centennial was contradictory in its perspectives. The composer could be honored by the left and the far right, by the conservative and the avant-garde, by the representatives of liberal, "apolitical" institutions, by the Austrian and German States, and by such intellectual franc-tireurs as Adorno.

Now, in my view, consensus here happens to be more interesting than difference, for it is against this background that Adorno's singularity emerges. There is one thing that most commentators disliked: Das Dreimäderlhaus, the operetta by Heinrich Berté, made out of tunes extracted from different Schubert works with a plot based on the 1912 novel Schwammerl by Rudolf Hans Bartsch. The piece had been staged from 1916 on with incredible success, not only in Vienna, but also in many other countries, including England in 1922 under the title Lilac Time. Bertés work concentrates a number of things in the contemporary culture that the critics felt bound to attack: the Biedermeierei, the "false" image of Schubert as a romantic naïf, a sort of garden gnome wandering through Vienna's forests. Such a concern appears in articles written by people as different as Rudolf Steglich, ${ }^{6}$ Heinrich Strobel, ${ }^{7}$ Alfred Einstein, ${ }^{8}$ Max Friedlander, ${ }^{9}$ Egon Wellesz, ${ }^{10}$ and Alban Berg. ${ }^{11}$ In 1928, Das Dreimäderlhaus is the absolute Schubertian evil, in a way that articulates - and often confounds - the critique of Romanticism and that of the recently discovered phenomenon of the massification of high culture.

Now, Adorno doubtless shares the other writers' contempt for the operetta: As evidence of a loss of the moving subjectivity in the truth character of this music, witness the transformation of Schubert the man into that repulsive specimen of petit bourgeois sentimentality, whose literary persona, it is true, Rudolf Hans Bartsch found in the figure of Mr Mushroom, but which secretly dominates all of today's Schubert literature coming out of Austria; and finally, 
as the endgame of the whole Romantic Schubert dreamscape, this sentimentality was behind the destruction of the dreamscape by Lilac Time. For obviously in this dreamscape the man has to shrink down so far that he no longer blocks the view he inspired in the first place, while not being completely driven out of its charmed circle, but which he must inhabit at the margin as the tiniest garden gnome.

As severe as this view may seem, Adorno nevertheless stays away from the simple contempt for kitsch voiced by his colleagues. "The discourse about kitsch becomes kitsch itself," he will write in $1932 .{ }^{12}$ In 1928 , distancing himself from the lamentation about a "true" Schubert betrayed by the Philistines, he links the score of Dreimäderlhaus, musically nothing else but a potpourri, to essential characteristics of Schubert's music. Adorno takes issue with

an image of Schubert that is false, both traditionally, and in its concept of the lyrical: for it views Schubert's music as a plant-like organism unfolding regardless of any preconceived form, or perhaps irrespective of any kind of form at all, and which grows and blooms so delightfully. Potpourri construction, on the other hand, denies the music anything to do with organistic theory. For such organic unity would have to be teleological: its every cell would necessitate the next one, and its coherence would speak of the living motion of subjective intention, although of a life that did actually stop, its revival surely not lying in the spirit of the potpourri. : . . . Even conceding that everything in Schubert's music is more grown than it is made, this growth, entirely fragmentary, and never sufficient, is not plantlike, but crystalline. $[: 22-23]$ 
According to Adorno, Berté's work, precisely because it belongs to the realm of low culture, captures historical truth. We might say that this truth is about the history of subjectivity. And this takes place at a technical level. In the Quintet of the first act, "Unter einem Fleiderbaum," Berté combines the theme of the Rondo of the D-major Piano Sonata and that of the Trauerwalzer in A-flat major D365, no. 2, to set Schubert and his friends Schober, Schwind, Kupelwieser, and Vogl. ${ }^{13}$ To do that, he transposes Schubert's melodies into the same tonality, G major; the triplets in the second part of the sonata theme, sung by Schubert's merry friends, allow for a seemingly natural transition to the ternary rhythm of the Trauerwalzer, where we hear Schubert's solo voice yearning for love, stimulated by the blossoming of spring. Thus musical continuity is apparently guaranteed. Yet the audience can recognize two distinct, self-contained entities, stemming from original musical contexts in which they are already presented as autonomous individualities, not as the material of an organic, developmental process. Faced with the ideology of bourgeois domestic happiness and its elaboration through a musical language classically bound to satisfaction, the critical representation of the individual's "erotic hopelesness" [:21] becomes possible precisely because the audience is already in command of that socially degradated vocabulary - the potpourri's broken pieces of Schubert's music.

Thus in Adorno's text the social critique of Schubert's image is linked to the philosophical critique of organicism. Granted, a comparison with other, later utterances by Adorno gives one the feeling that his discussion of organicism remained throughout unstable, often contradictory. Yet without claiming that he was the first to utter such a critique in the musical field (a case can be made for some of Heinrich Schenker's early writings, discussed by William A. Pastille ${ }^{14}$ ), we might think that what he says about Schubert in 1928 amounts to a unique contribution to the composer's reception and a significant moment in the history of musical thought, with consequences on both the political and the theoretical level. 
As to the political aspects, it is worth comparing Adorno's view with that of Richard Benz, in his völkisch-Nietzschean manifesto heralding "a renewal of culture through the sprit of music." ${ }^{15}$ In "Franz Schubert, der Vollender der deutschen Musik," Beethoven is named the "Christ of the German religion" and Schubert Beethoven's "greatest apostle," for, according to Benz, Schubert "translates the new religion into the popular language." Even his instrumental music contributes to a "spiritual Volksgemeinschaft," for in it "the song that is immediately comprehensible to the people integrates organically into the rest of the singing." Benz's ideas form a good example of the pervasiveness of the organicist paradigm that inhabits his description of the whole web of mediations between music, the genial artist, and the Volk. The political implications of such a discourse were blatant in Weimar Germany, for it linked in a pretty effective way the collective ethos of the new proto-fascist ideologues with the by then traditional role of the musical canon as a practical actualization of national identity. From that point of view, Adorno's Schubert was certainly not a candidate for joining in the choir.

At the same time, on a different level, Adorno's critique of organicism points to theoretical issues. In 1928, Felix Salzer published his pioneering study on Schubert's sonata form. There, this pupil of Schenker points out the importance of "lyrical," closed thematic structures, organized as ABA Lied forms, in Schubert's expositions. The practice, he thinks, undermines the strength of the open-ended "improvisatory" elements in which he sees the essence of the "organic" sonata form. In this, adds Salzer, Schubert deviates from the main evolutionary trend represented by the works of C.P.E. Bach, Haydn, Mozart and, of course, Beethoven. Hence Salzer makes an overall negative judgement, which James Webster has called an "anti-Schubert bias."16

Salzer identifies such a Lied form in the exposition of the Piano Sonata in B-flat major: after the first statement of the main theme and its varied repetition as a Nachsatz, its 
transposition into G-flat major amounts to a B-section followed by a return to B-flat major. Although it completes the symmetrical ternary form, this return, for Salzer, lacks "necessity." At the same time, the transposition is no actual modulation, but an unfolding of the flattened sixth degree - a fact that supposedly confirms the absence of forward movement.

Significantly enough, Salzer says nothing of the development of this sonata, which is less characterized than many others by direct transpositions of the exposition's material. Nor, for that matter, does he speak of the recapitulation, which actually could have provided him with a good example of the kind of Transpositionsreprise that he envisions as another of Schubert's flaws. ${ }^{17}$

We can compare this view with that of another pupil of Schenker, Otto Vrieslander. At the International Schubert Conference held in Vienna for the Centennial, Vrieslander gave a paper entitled "The Organic in the 'Heavenly Lengths' of Schubert." ${ }^{18}$ His view of the first group of the B-flat major Sonata as a Lied form is identical to Salzer's, yet he admires the fact that "one single specifically lyrical idea, using only a minimum of harmonic steps, does not simply burst the form, thus exposing to great dangers the continuation of the structuring of the Sonata." Vrieslander skips the second group, where he sees only "a development made according to the rules," to summarize his view of the whole exposition as "an entire, great assembly of events, each closed in itself," resulting in “"organic' length.” Later, Vrieslander concentrates on the Durchführung, showing that what he calls the fourth Gedanke (bars 151ff) derives directly from subsidiary material in the exposition. Followed by the repeat of the first theme, this move heralds a recapitulation "effected in the most organic way."

Salzer and Vrieslander both invoke organicism to sustain diametrically opposed views of Schubert's music. Now let's compare their analysis of the B-flat-major Sonata to what Adorno says about this work: 
It is not for nothing that the moods in Schubert, which not only revolve, but can also collapse, are bound up with harmonic shifts, with modulation, which sheds light, at whatever level of profundity, on things that are always the same. Those sudden, non-developmental modulations occlude daylight like camera shutters. [...]

This is the case of the second subject in the first movement of the B-flat-major Sonata, says Adorno, commenting that such a move has "transformed the links in the sonata model entirely into a collapse of perspective that opens up harmonic depth." He adds that the fact that in this major-mode work "the second subject appears to move towards the minor means, according to the modal symbolism that still held true for Schubert, a real step into the dark."

Adorno focuses precisely on the one part of the exposition that Vrieslander and Salzer had chosen to skip. Granted, he does not go into analytical detail; maybe this was the kind of shortcoming he had in mind when in 1963 he introduced the republication of his 1928 article in his book Moments Musicaux by saying that "the philosophical exegesis proceeds in too immediate a way, without duly taking into consideration the technical and compositional elements [of the music]." ${ }^{19}$ Yet he does stress harmony-determined discontinuities, not motivic coherence, nor dynamic structural processes. And these discontinuities are in his view symptomatic of the thematic and formal conditions of Schubert's music which relate to the expression of subjectivity in music and its sociological and historical determinations. By distancing himself from the organicist dogma that could lead to such opposite conclusions as Salzer's and Vrieslander's, Adorno introduces into the Schubert literature an insight that could foster a new interpretive paradigm, but one that can only nowadays be recognized as such.

This whole discussion is not without a link to Adorno's relationship with Schoenberg. After having spent several months in Vienna taking lessons from Alban Berg, Adorno in 1928 was actively engaged in what he would soon call, in a letter to Berg, "Schoenbergian 
politics." ${ }^{20}$ The Schubert Centennial coincided almost exactly with the first performance of Schoenberg's Variations, Op. 31, by Furtwängler and the Berlin Philharmonic. The concert also featured Schubert's "Great" Symphony in C, a fact that led one of the few sympathetic critics to claim that Schoenberg's work allowed him to view Schubert's in "a new light.,"21 But the event was actually a scandal. Adorno's published a review in Anbruch in January 1930. ${ }^{22}$ He praises it Op. 31 a masterwork, saying that "to understand it means nothing else but to recognize the crystalline structure it has in itself, bare of any scale imposed from without." This crystalline structure, Adorno thinks, results from a compositional impulse in which construction and imagination do not oppose each other, thanks to the twelve-tone technique and, in particular, to the systematic exploitation of transposition. This has nothing to do with "a sense of a modulatory development"; on the contrary, it amounts to an abandonment of "the last bits of slag of the essence of the functional cadence."

Thus, we here encounter once again the idea of the "crystalline" that Adorno had applied to Schubert's music, as opposed to any vegetal metaphor. In this view, Schoenberg achieved a liberation from every schema inherited from the "organic-dialectical sonata" without even using an "organic cover," as Schubert continued to do. In both cases, theirs is a "second formal practice," a crystalline landscape. The wanderings of the crystal metaphor show that for Adorno, at that time, both Schubert and Schoenberg represented alternatives to a musical canon centered on the organic, tonal, sonata form. We are here as far from garden gnomes as it is possible to be.

This alternative view, which in the cultural field of Weimar Germany amounted to a truly political stance, was enhanced by the fact that, for Adorno, Schubert and Schoenberg are related at the level of ethical significance. The ethical dimension of Schoenberg's work was a long-held conviction, and one of the reasons for Adorno's taking a stance in "Schoenbergian politics" in the first place. One of its most explicit formulations appears at the end of the first 
part of Philosophy of the New Music: “[Schoenberg's music] has taken upon itself all the darkness and guilt of the world.... It is the true bottle thrown into the sea." In that book, Adorno also says that the composer, in his atonal period, freed music from the "bourgeois taboos of expression" by recording "seismographically" the instinctual drives of the Freudian Id. $^{23}$

Written some twelve years before these remarks on Schoenberg, the essay on Schubert also ends with praise of the utopian dimension of the composer's music. Here as well, the seismograph provides a metaphor for understanding the music's symptomatic condition:

In jagged lines, like a seismograph, Schubert's music has recorded the message about people who have experienced a qualitative change. And that means tears, the desperately sentimental tears of Lilac Time, or those that simply well up in the body. In the presence of Schubert's music tears just pour from our eyes, hidden from the soul: this is the stark reality with which this music moves us. We cry without knowing why, because we are not yet as that music promises. We cry, knowing deep down that this music is as it is in the promise of what one day we ourselves shall become. This is music we cannot decipher, but it holds up to our welling, fading eyes the secret of infinite reconciliation. [:33]

The seismograph connects with the structure of social reality and that of subjectivity itself. For Adorno, understanding Schoenberg's or Schubert's music is tantamount to an insight into the deepest contradictions and hopes of society. The relevance of this idea can still be debated today: despite its originality and power, Adorno's thought is but one of the brightest examples of a tradition of social exegesis based on the ideological assumption of a necessary homology between normative systems operating within very different social practices - namely, music and political domination. Recognizing the historical contingency of 
that assumption, which in Adorno's case is rooted in Hegel's philosophy, could lead us away from the temptation of becoming "Adornian." Yet if we assume that the contemporary critique of organicism was launched by a famous article published by Joseph Kerman $1980,{ }^{24}$ that is, more than half a century after the "Schubert" essay, we might think that Adorno's contribution to music theory, which associates the theoretical dimension with the cultural history of music, has still to be properly analyzed as a historical phenomenon and used as a heuristic tool for today's debates in the musicological field.

\footnotetext{
${ }^{1}$ Theodor Wiesengrund-Adorno, “Schubert,” Die Musik, 21 (1928), pp. 1-12.

${ }^{2}$ G. Jean-Aubry, "Schubert's Geist," The Chesterian X/n74, London, translated in Die Musik 21 (1929), p. 287.

${ }^{3}$ Leo Kestenberg, "Revolutionär des Liedes," quoted in Die Musik 21 (1929), p. 284.

${ }^{4}$ P. Friedländer, Die Rote Fahne, 18 November 1928, quoted in Die Musik 21 (1929), p. 285.

${ }^{5}$ Max Friedlander, “Ansprache zur Einführung," Bericht über den internationalen Kongress für Schubertforschung. Wien 25. bis 29. November 1928 (Augsburg: Benno Filser, 1929), p.
}

3.

${ }^{6}$ Rudolf Steglich, “Das Vermächtnis Franz Schuberts,” Zeitschrift für Musik 95 (1928), p. 610.

${ }^{7}$ Heinrich Strobel, "Musikleben," Melos 7(1928), p. 556.

${ }^{8}$ Alfred Einstein, “Schubert. 17.November 1928,” Berliner Tageblatt (17 November 1928)

${ }^{9}$ Friedlander, p. 20.

${ }^{10}$ Egon Wellesz, in "Franz Schuberts 100.Todestag," Vossische Zeitung (18 November 1928)

${ }^{11}$ Alban Berg, in “Franz Schuberts 100.Todestag," Vossische Zeitung (18 November 1928). 
${ }^{12}$ Theodor W. Adorno, "Kitsch” [ca.1932], in Gesammelte Schriften 18 (Frankfurt-am-Main:

Suhrkamp, 1984), pp. 791-794.

${ }^{13}$ See Robert Morris, "Of Mushrooms and Lilac Blossom,”

http://myweb.tiscali.co.uk./franzschubert.

${ }^{14}$ William A. Pastille, "Heinrich Schenker, Anti-Organicist,” this journal 8 (1984): 29-36.

${ }^{15}$ Richard Benz, Franz Schubert, der Vollender der deutschen Musik (Iena: Eugen

Diederichs, 1928). On Benz's Die Stunde der deutsche Musik, see David B. Dennis,

Beethoven in German Politics (New Haven and London: Yale University Press, 1996), pp.

128-129.

${ }^{16}$ James Webster, “Schubert's Sonata Form and Brahms's First Maturity,” this journal 2 (1978): 18-35.

${ }^{17}$ Felix Salzer, "Die Sonatenform bei Franz Schubert," Studien zur Musikwissenchaft 15 (1928), pp. 99-100.

${ }^{18}$ Otto Vrieslander, “Das Organische in Schuberts 'himmlischer Länge,’” Bericht über den internationalen Kongress für Schubertforschung, pp. 219-232.

${ }^{19}$ Theodor W. Adorno, Moments Musicaux, trans. M. Kaltenecker (Geneva: Contrechamps, 2003), p. 6.

20 Theodor W. Adorno to Alban Berg, 9.10.1929, in Theodor Adorno and Alban Berg, Correspondance 1925-1935, trans. M. Dautrey (Paris: Gallimard, 2003), p. 227.

${ }^{21}$ Max Marschalk, Vossische Zeitung (4 December 1928); quoted in Carl Dahlhaus, Schoenberg, (Geneva: Contrechamps, 1997), p. 100.

${ }^{22}$ Theodor W. Adorno, “Schönberg: Variationen für Orchester, op. 31,” Anbruch 12/1 (January 1930): 35-38, in Gesammelte Schriften 18, pp. 370-375.

${ }^{23}$ Theodor W. Adorno, Philosophie de la nouvelle musique (Paris: Gallimard, 1962), pp. 53, $58,142$. 
${ }^{24}$ Joseph Kerman, "How We Got into Analysis, and How to Get Out", Critical Inquiry 7

(Winter 1980): 311-331. 